\title{
Cost of German Scientific Publications
}

$\mathrm{T}$ HE high prices of German scientific publications, to which reference has been made in Nature $(132,34$ and $540 ; 1933)$, are again discussed in Angewandte Chemie of March 9 . The chief factors in the increased cost are the decreased demand, increased cost of paper, binding, type and setting and illustrations, as well as overhead charges, decreased revenue from advertisements resulting from diminished circulation, the publication of smaller editions to avoid getting out of date, with consequent heavier on-costs, and the high discounts afforded to German booksellers. It is asserted that every effort is being made at compression to compensate for the 15-20 per cent greater space normally required for a German book as compared with the same work in French or English, and that the 'Münster Agreement' of 1933 (between librarians, publishers and the university unions, representing the authors) has in this way already resulted in an estimated decrease of $2,000,000$ gold marks in costs of publication.

The prices of books and journals have been reduced, but only exceptionally has the cost per page been reduced, chiefly due to the technical costs of production which are not under the publisher's control. It is estimated that the cost of setting and printing is about 95 per cent above that of 1913 ; plates and line blocks are 60 and 150 per cent dearer, paper 12 pər cent and bookbinding 100 per cent above the 1913 charges, representing an average increase of 50 per cent, or more for many important books. Author's fees have also increased, but are being reduced, and are now little above the pre-War figure. This factor, however, reacts adversely on the demand, since authors form an appreciable proportion of the purchasers of scientific works. During 1934, imports of foreign journals into Germany decreased 16 per cent in volume as against 12 per cent by value, indicating increased costs of production elsewhere, while exports of German literature decreased by $13 \cdot 1$ per cent in volume and $16 \frac{1}{3}$ per cent in value, indicating a fall in German prices.

On-costs in particular have increased both actually and relatively, and are still tending to rise owing to industrial conditions and diminished output. Publicity charges are more than 50 per cent higher than in 1913 , taxation is at least four times as great, rents are 20 per cent, heating and lighting 27 per cent higher, and 20 per cent of the turnover in advertisements has to be contributed to the trade council. Postage charges are about 20 per cent higher and for such journals as Angewandte Chemie and Die Chemische Fabrik amount to 15 per cent of the total cost of publication. Salaries and wages are estimated at 25-100 per cent above the 1913 level. The size of editions is one of the most difficult problems confronting the publisher. Profits can only be made on sales in excess of a certain minimum, and to promote sales by diminishing costs, endeavours have been made to issue new editions of textbooks every seven or eight years instead of three or four years, but there are limits to such efforts imposed by the rapidity of scientific developments. Foreign sales have diminished enormously for political reasons as well as through increased competition, and for reasons similar to those operating internally. Advertisement revenue has assisted considerably in the reduction of the price of certain journals of applied science, but only amounts to about one third of the revenue from this source in 1929-30. Retail and wholesale booksellers in Germany demand a 25-30 per cent discount as against $15-16 \frac{2}{3}$ per cent abroad, and the trade is overcrowded. The reduction in the average price of German books from 8.36 to 4.32 gold marks in four years is largely due to the special cheap editions issued by the million, and is not reflected in scientific books, the purchasers of which have been heavily hit financially.

Increased purchasing power, decreased taxation and costs of production with further efforts at condensation are the only hopeful means of increasing the circulation. The American proposal to publish only the more important scientific papers, retaining the majority in manuscript and providing photostats as required, is severely criticised as fatal to publica. tion of scientific knowledge and its effective circulation.

\section{Copepods from West Greenland Waters*}

$\mathrm{A}^{\mathrm{N}}$ $\checkmark$ important collection of pelagic copepods is described by Dr. P. Jespersen from the waters west of Greenland in the Davis Strait and Baffin Bay, with one station to the south-west of Iceland. The submarine ridge across the narrow part of the Davis Strait with a maximum depth of 700 metres forms an effective barrier to the migrations into Baffin Bay of many Atlantic species the habitat of which is deeper than this; the depths to the south of the ridge exceeding 3,500 metres and the depths in Baffin Bay amounting to at least 2,000 metres. Warm Atlantic water predominates in the sea area south of the Davis Strait, but along the west coast of South Greenland the East Greenland polar current makes its way round Cape Farewell, and in the most western part of this area there are several stations, taken by the expedition, situated in the cold Labrador current.

* Meddelelser om Grønland udgivne af Kommissionen for Videnskabelige Undersøgelser i Grønland. Bd. 79, Nr. 10: The Godthaab Expedition 1928-Copepoda. By P. Jespersen. Pp. 166. (Kobenhavn: C. A. Reitzels Forlag, 1934.) $8.00 \mathrm{kr}$.
A part of the Atlantic water passes over the submarine ridge in the Davis Strait and up into Baffin Bay, where it forms an intermediate layer below the surface with a positive temperature. The bottom water of Baffin Bay has on the contrary a negative temperature of about $-0 \cdot 4^{\circ}$. The temperature conditions alone thus form a natural limit to the northward advance of certain species.

The species are divided into two main groups: those which are found in the whole area investigated and those which are exclusively, or to a predominant degree, found in the waters south of Davis Strait; 23 species being found in the first and 76 species in the second division. Davis Strait thus appears to form the northern limit of distribution for a large number of Atlantic species, and it is specially those found in fairly great depths that cease to penetrate northwards and those more frequently caught in the upper layers which occur in the whole area. Most of the species are oceanic and no species were found 
which in a pronounced degree are restricted to the Arctic sea areas. Indeed Dr. Jespersen states that "it is certainly a question whether among the oceanic copepods there are any distinct arctic forms at all".

The most frequent species were Calanus finmarchicus, Calanus hyperboreus, Metridia longa and young stages of the genus Pareuchota. Calanus finmarchicus predominates in the hauls from the south of Davis Strait and the numbers are considerably reduced in Baffin Bay. In Smith Sound, much farther north, it is again abundant in the surface layers. Calanus hyperboreus, which likes cold water, is found only in small quantities south of Davis Strait, in the Strait itself in the upper layers being more abundant and in Baffin Bay present in small quantities. Metridia longa occurs in small quantities south of the Davis Strait and in the upper layers of the Strait itself, but occurs in fairly large numbers in Baffin Bay. Pareuchceta in its young stages is found in the water south of Davis Strait and only in small quantities in the Strait itself and in the more northern parts investigated.

Details of distribution and biology of all the species are given whenever possible with much interesting information, and many species are shown to have a more northerly distribution than was known before. A series of tables and curves is also provided. One new species was found, Euchoeta Wilsoni, and this is represented by only one specimen.

\section{All-Metal Radio Receiving Valves}

$I^{\mathrm{T}}$ will be recalled that about two years ago the 'Catkin' series of receiving valves was first produced in Great Britain (see NATURE, 131, 735 ; 1933). In the construction of this valve, the amount of glasswork was reduced to a considerable extent, the upper portion of the envelope being formed of the eylindrical copper anode, which was sealed to the lower glass portion by a vacuum-tight joint. Now, an entirely new series of literally all-metal receiving valves is announced by the General Electric Co. of America, and brief details of these were given by the New York representative of the Wireless World in the issue of that journal of April 19. These new valves employ a cylindrical outer shell of stecl or iron welded to a metal base which rigidly supports the electrode system. The lead-in wires from the electrodes are strung through beads of glass, which are then placed in eyelets of a new alloy known as Fernico, which lines the holes in the base of the valve. The assembly is then passed through a gas flame which fuses the glass beads so that they fill the eyelets. Fernico is an alloy of iron, nickel and cobalt which has the same coefficient of expansion as the beads of glass employed, so that the seal is accom. plished without setting up strains in the fusing process. After the electrode system has been attached to the leads, the metal outer shell is placed over the structure and welded to the base. The valve is now exhausted through this metal tube, which is then clamped, welded and cut off at the appropriate time.

The use of an all-metal construction enables the valves to be made smaller in dimensions than existing glass valves, with corresponding reduction in lengths of leads and inter-electrode capacitances. The valves may therefore be of higher amplification factors with out instability, and should retain their efficiency at shorter wave-lengths than existing types. Further, since the metal shell completely surrounds the valve and is maintained at earth potential, there will be no necessity for shielding the valve after it is placed in its socket in the receiver. At the present time, six types of all-metal valve have been put into production at the R.C.A. Manufacturing Co., which will make the valves for the General Electric Co. It is expected that now receivers designed round the metal valve will be produced by the autumn of this year.

\section{Physical Methods in the Study of Earth Structure}

$\mathrm{T}$ HE increasing specialisation of science and its literature inspires an ever-growing demand for expositions of separate branches in terms suitable for workers in other fields. The effort to prepare such accounts is often beneficial to those who provide as well as to those who hear or read them; but some stimulus for their provision is needful, and notable among the available effective stimuli are the endowed annual lectureships of such bodies as the Institution of Civil Engineers. This is well exemplified in the forty-first James Forrest Lecture, delivered to that Institution on May 7 by Prof. O. T. Jones, who took geophysics as his subject.

The choice by a geologist to lecture on geophysics might in past years have led to a passionate or scornful attack on the geological ignorance of geophysicists; but even in this age of tolerance, Prof. Jones is notable among geologists for his sense of the importance of physical methods in studying the problems of the earth. He has, in fact, produced an admirably clear account of the subject, after modestly disclaiming any rôle save that of the exponent. So calm is the 'atmosphere' of his address that the geophysicist may even feel a craving for at least some more distinctively geological criticism or flavour. But in the closing part of the address Prof. Jones made a most interesting reference to a British problem that is of interest alike to geologists, geophysicists and engineers.

In many parts of the British Isles, Prof. Jones stated, there are known to be many deep rock channels that are so filled with various materials that their existence has not been suspected until engineering explorations for railways, roads, tunnels or sites for reservoirs have revealed them. Some of them are known to be post-glacial : others, being filled with glacial drift, must be pre-glacial. It is still uncertain whether these latter are due to normal river erosion, in which case their gradient must have been continuously downward to the sea-level of their period; or whether they have been excavated by streams flowing below the ice, in which case they 